\title{
Habitat change in estuaries: predicting broad-scale responses of intertidal macrofauna to sediment mud content
}

\author{
Simon F. Thrush*, Judi E. Hewitt, Alf Norkko, Pip E. Nicholls, Greig A. Funnell, \\ Joanne I. Ellis
}

National Institute of Water and Atmospheric Research, PO Box 11-115, Hamilton, New Zealand

\begin{abstract}
There is a growing threat of habitat change in estuarine and coastal regions, yet there are few models that enable ecologists and resource managers to forecast the response of macrofaunal species to long-term changes in sediment type. This study details a novel strategy that enabled us to rapidly collect data on macrofaunal densities and sediment characteristics by sampling mud-to-sand transition zones in 19 estuaries. Species-specific models that predict probability of occurrence relative to sediment mud content were developed for 13 common macrofaunal species. However, the roles played by many macrofaunal species are influenced by density, not just occurrence. Over broad spatial scales, the constraint an environmental variable places on density can be represented by the upper (or lower) limit on density. Thus, the distribution of maximum density along the gradient from mud to sand was modelled as another indicator of a species' preference. Both the maximum and minimum values for number of taxa, number of individuals, Shannon-Wiener diversity and taxonomic distinctness were also modelled. For most variables, good models $\left(\mathrm{r}^{2}>0.6\right)$ were developed. The models developed for the different species exhibited a wide variety of functional forms, highlighting the potential variation in response to habitat change even for closely related species with similar natural history characteristics. Probability-of-occurrence models and maximum-density models for a specific species also varied in functional form, emphasising that changes in both occurrence and density need to be considered when predicting likely responses to changes in habitat.
\end{abstract}

KEY WORDS: Habitat change · Macrofauna $\cdot$ Sediment grain size $\cdot$ Logistic regression · Factor ceiling responses $\cdot$ Transition zones $\cdot$ New Zealand

\section{INTRODUCTION}

There is a growing need to predict ecological responses to long-term habitat change in estuarine and coastal ecosystems. In this regard, statistical models are useful tools that relate ecological variables to environmental factors, often over broad scales that are not amenable to manipulative experiments. Statistical modelling of species-habitat relationships requires data from a number of locations over a wide range of habitats. Such models take a top-down view of ecological systems and seek to identify general results at the expense of small-scale detail. For many areas under significant threat of habitat change, data are often sparse, thus emphasizing the need to develop techniques to gather data rapidly as well as to develop models that reveal underlying relationships.

The rate and extent of habitat change in estuarine and coastal ecosystems is likely to increase as a consequence of global warming. For many parts of the planet, including New Zealand, climate projections indicate that sea level will rise, rainfall will be more intense and the frequency of storms will increase (Burkett et al. 2001). Sediment runoff from land and rapid sedimentation events within estuarine and coastal regions may become more common due to climatic 
variability compounded by changes in resource utilization and exploitation by humans (Fowler \& Hennessey 1995, Wheatcroft 2000). The distribution and diversity of estuarine and coastal benthic habitats will be influenced by inundation of wetlands and marshes, alteration of shorelines, and changes in the patterns of erosion and deposition, all of which are likely to result in changes in sediment type.

In soft-sediment ecology, there is a long history relating the distribution and abundance of macrofauna to sediment particle size (e.g. Thorson 1950, Rhoads \& Young 1970, Probert 1984). Broad-scale differences in assemblages in sand and mud habitats are readily apparent (e.g. Gray 1974, Beukema 1976, Zajac \& Whitlatch 1982, Meire et al. 1994, Mannino \& Montagna 1997, Ysebaert et al. 2002). However, when relationships between sediment characteristics and the distribution and abundance of macrofauna have been identified, elucidating the underlying mechanisms has proved elusive (Butman 1987, Snelgrove \& Butman 1994). Many oceanographic and biogeochemical processes usually co-vary with sediment particle size, and the resident organisms themselves further modify the sediments, influencing local physical and chemical characteristics. Given the strong feedback relationships between some species and local sediment characteristics, it is not surprising that simple cause-andeffect relationships have been difficult to define. Since deterministic models that are able to predict the distribution and abundance of species relative to changes in the sedimentary habitat have proved difficult to construct, statistical modelling is a useful tool.

The aim of this study was to develop models that forecast (sensu Legendre \& Legendre 1998) how the distribution and abundance of species is likely to change with changes in sediment particle size. Forecasting models of this type provide insight into chronic habitat change such as increased muddiness; they do not provide insight into the acute effects associated with disturbance events such as catastrophic deposition of terrestrial sediment (e.g. see Norkko et al. 2002, Cummings et al. 2003, Hewitt et al. 2003, Thrush et al. 2003). We developed statistical models mindful of the patchy spatial distributions exhibited by macrofauna over a wide range of scales (McArdle \& Blackwell 1989, Thrush 1991, Hewitt et al. 1996, 1997a, Legendre et al. 1997). One solution to this problem is to limit the analysis to presence/absence data and develop models of the probability of occurrence of species. Ysebaert et al. (2002) used logistic regression to derive response surfaces of the probability of occurrence for 20 common macrobenthic species in the Schelde estuary, Netherlands. By combining disparate data sets, these authors were able to develop effective models dealing with broad-scale distribution patterns within the estuary based on salinity, depth, current velocity, and sediment characteristics.

However, the roles played by many macrofaunal species are influenced by their density not just occurrence. Also, species that exhibit broad tolerance to environmental conditions (as is often considered to be the case for estuarine species) might not be those for which sensitive models could be developed on the basis of occurrence alone. Occasionally, increased probability of occurrence can reflect increased density as for example when a more ubiquitous spatial distribution or increased size of patches increases the likelihood of sampling the species of interest. However, an increased probability of occurrence does not reflect spatial heterogeneities that result in patches of elevated density, or, thus, responses that are driven by changes in density within a patch. Furthermore, postlarval dispersal, common in soft-sediment organisms, may result in a high probability of transients being detected in a habitat, thus further constraining the sensitivity of models of species occurrence.

Modelling changes in abundance rather than occurrence is likely to reveal extra information on the sensitivity of species to environmental factors, although modelling changes in mean abundance is not necessarily the most ecologically insightful method. A common phenomenon in ecology is for data points in scatterplots of the relationship between biotic factors, or between biotic and environmental factors, to be widely scattered beneath an upper (or above a lower) limit - a phenomenon described by Thomson et al. (1996) as a 'factor ceiling'. The ceiling to the data scatter implies a constraining factor, thus the form the ceiling takes allows us to derive maximum (or minimum) possible response curves to an environmental variable. This implies that, over broad scales, while a number of factors (e.g. the potential for recruitment, historical conditions, other competitors/predators) may affect the observed density, there is a limit (frequently an upper limit) that is controlled by the variable of interest. Herein, we model both probability of occurrence and maximum abundance to improve our understanding of the response of estuarine macrofauna to increasing sediment mud content (i.e. sediment particles $<63 \mu \mathrm{m}$ in diameter).

To identify the relationships between the distribution and abundance of macrofauna and sediment particle size, we focused our sampling along the mud-tosand transition zone of estuarine intertidal flats. This enabled us to sample over a wide range of sediment particle size in a large number of estuaries with minimum spatial extent/effort within each estuary. By limiting the spatial extent of sampling within an estuary, we tried to minimize confounding of our analysis by factors such as estuary-wide variations in salinity or 
recruitment. In developing the statistical models, we did not include all factors in the model that might be influencing the distribution and abundance of an individual species. In particular, for models predicting changes in abundance, we used an approach analogous to that of Blackburn et al. (1992) for modelling the energetic constraints on body size, which is consistent with the factor-ceiling concept (Thomson et al. 1996). That is, while sediment mud content is unlikely to be the only factor influencing the distribution and abundance of species, it is likely to influence the maximum abundance attained by that species in any particular sediment type.

\section{MATERIALS AND METHODS}

Survey design. The intertidal areas sampled were located in the top half of the North Island of New Zealand; they encompass a geographic extent of about $600 \mathrm{~km}$ and are connected with either the Pacific Ocean or the Tasman Sea (Fig. 1). The estuaries, harbours and embayments surveyed represent a wide section of estuarine characteristics, ranging in area, tidal exchange, morphology, and habitat diversity (Table 1). However, all the areas sampled have low freshwater inputs relative to the tidal exchange and typically maintain high salinity, similar to that along the adjacent coast. Samples were collected in spring and early summer, i.e. between October and December 2000.

In order to balance sampling effort against collection of data from as many estuaries/embayments as pos-

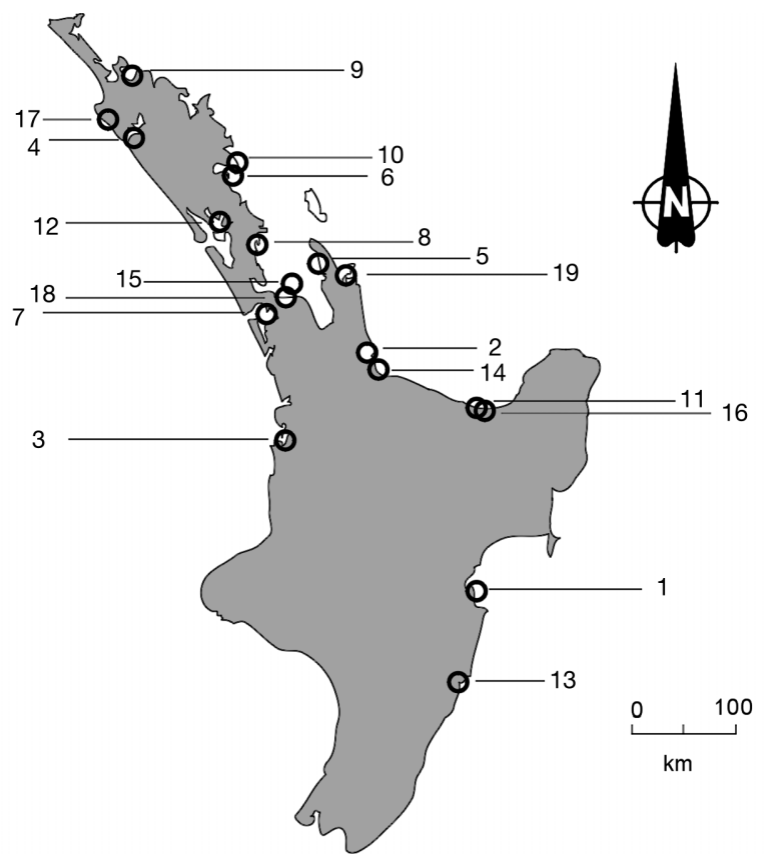

Fig. 1. North Island of New Zealand showing sampling sites: (1) Ahuriri; (2) Bowentown; (3) Kawhia; (4) Koutou; (5) Manaia; (6) Mangawhai; (7) Manukau; (8) Matakana; (9) Mangonui; (10) Ngunguru; (11) Ohiwa; (12) Otamatea; (13) Porangahau; (14) Te Puna; (15) Waiheke; (16) Waiotahi; (17) Whangape; (18) Waikopua; (19) Whitianga

sible, sampling was focused along 1 transect over the mud-to-sand sediment interface within an intertidal habitat at each locality. The particular interface was

Table 1. Date of sampling and general features of the estuaries, harbours and embayments sampled. Mean tidal range was calculated at mouth of the estuary, harbour or embayment

\begin{tabular}{|c|c|c|c|c|}
\hline Site & Estuary type & Area $\left(\mathrm{km}^{2}\right)$ & Mean tidal range (m) & Catchment area $\left(\mathrm{km}^{2}\right)$ \\
\hline Ahuriri & Tidal lagoon & 2.75 & 1.4 & 143.5 \\
\hline Bowentown (Tauranga) & Tidal lagoon & 200.4 & 1.5 & 1299.7 \\
\hline Kawhia & Drowned valley & 67.6 & 2.3 & 498.6 \\
\hline Koutou (Hokianga) & Drowned valley & 106.5 & 2.1 & 1604.9 \\
\hline Manaia & Coastal embayment & 6.4 & 2.4 & 59.2 \\
\hline Mangawhai & Tidal lagoon & 4.8 & 1.8 & 11.7 \\
\hline Wiroa Island (Manukau) & Drowned valley & 365.6 & 2.2 & 1022.6 \\
\hline Matakana & Tidal lagoon & 4.2 & 2.1 & 50.2 \\
\hline Mangonui & Tidal lagoon & 8.7 & 1.6 & 75.6 \\
\hline Ngunguru & Tidal lagoon & 5.1 & 1.7 & 86.6 \\
\hline Ohiwa & Tidal lagoon & 26.8 & 1.5 & 185.6 \\
\hline Otamatea (Kaipara) & Drowned valley & 743.1 & 2.2 & 6265.9 \\
\hline Porangahau & Coastal lake & 2.7 & 1.3 & 846.0 \\
\hline Te Puna (Tauranga) & Tidal lagoon & 200.4 & 1.5 & 1299.7 \\
\hline Awaawaroa Bay (Waiheke) & Coastal embayment & 2.8 & 2.5 & 14.1 \\
\hline Waiotahi & Tidal lagoon & 10.0 & 1.5 & 148.0 \\
\hline Whangape & Drowned valley & 101.3 & 2.1 & 301.4 \\
\hline Waikopua (Whitford) & Drowned valley & 11.1 & 2.4 & 61.0 \\
\hline Whitianga & Tidal lagoon & 15.5 & 1.5 & 450.3 \\
\hline
\end{tabular}


haphazardly selected, but tended to run parallel to the shore to reduce confounding by changes in tidal elevation. Another potential confounding factor for any single survey, particularly when conducted at multiple locations, is major recruitment or post-settlement movement events (e.g. Hewitt et al. 1997b). To dampen the potential effect of such temporal variability, only the large macrofauna (>1.0 $\mathrm{mm}$ ) were sampled.

Sample collection and analysis. Sampling transects varied in length between localities; they started in soft muddy sediment, often near the edge of mangrove habitats, and ended on firm sand. Each transect was divided into 12 strata and the positions of haphazardly chosen sample locations within each strata were recorded using a handheld GPS, and a theodolite to measure elevation. At each sampling position, 2 macrofaunal cores (13 cm in diameter and $15 \mathrm{~cm}$ deep) separated by about $1.0 \mathrm{~m}$ were collected. Sediment geotechnical properties were measured using a penetrometer and shear vane. Quadrats $\left(0.25 \mathrm{~m}^{2}\right)$ were photographed to quantify crab burrow density (the only large and abundant bioturbating infauna observed). A core ( $1.5 \mathrm{~cm}$ in diameter and $2 \mathrm{~cm}$ deep) was collected to determine sediment particle size and organic content; another core was collected to assess benthic chlorophyll a. Only the surficial sediments were sampled, because they are geologically recent and reflect settlement surfaces for colonists, and influence food availability and pore-water transport.

Macrofauna were preserved in $70 \%$ isopropyl alcohol, stained with $0.2 \%$ Rose Bengal, sorted, and identified to the lowest taxonomic level practicable. To determine particle size, samples were digested in $6 \%$ hydrogen peroxide for $48 \mathrm{~h}$ to remove organic matter. Wet-sieving was used to measure cumulative percent weights of gravel, coarse sand, medium sand, fine sand, and mud sediment fractions (i.e. particles sizes of $>2,2-0.5,0.5-0.25,0.25-0.063$ and $<0.063 \mathrm{~mm}$ respectively). Organic content was measured as loss on ignition over $5.5 \mathrm{~h}$ at $400^{\circ} \mathrm{C}$, after drying the samples at $60^{\circ} \mathrm{C}$ for $48 \mathrm{~h}$. Sediment samples for chlorophyll a analyses were kept chilled and in the dark while in the field, frozen as soon as possible and then freezedried on return to the laboratory. Chlorophyll a was extracted from sediments by boiling in $95 \%$ ethanol, and the extract was analysed using a spectrophotometer. An acidification step was used to separate degradation products from chlorophyll a (Sartory 1982).

Statistical analysis. We used 2 types of models to investigate the effect of sediment mud fraction on the distribution and abundance of individual species. Firstly, the probability of occurrence was modelled using logistic regression of presence/absence data. The use of the logistic link allowed the probability of occurrence function to vary from a near linear to either an S-shaped curve (for a first-order linear predictor) or to a Gaussian curve (for a second-order polynomial). Secondly, the maximum abundance expected to occur was modelled following the methods proposed by Blackburn et al. (1992). For these models, the sediment mud fraction, which varied over all samples from 1.5 to $88 \%$, was divided into 10 equal classes (i.e. 0-9, $9.1-18 \%$, etc.), and the maximum density of an individual species found in each class calculated. Models of the maximum density vs sediment class mid-point were derived using linear, log, second-order polynomial and Gaussian functions, and were weighted by the number of samples occurring in each class. Model fit was evaluated by visual inspection of half-normal plots of residuals together with plots of residuals vs predicted values as well as consideration of percent concordance for logistic regression. The final model used for each species was that function which explained the most variability.

The species abundances used in the models were the sum of the 2 cores taken at each sampling position. For both types of model, localities were included when the species occurred at a density of $>1$ individual per pair of cores at one position. As the corer used to sample macrofauna may be have been inadequate to estimate the density of crabs, models were also developed for the number of crab burrows counted in the quadrats.

Community-level variables, number of taxa, number of individuals, Shannon-Wiener diversity $\left(H^{\prime}\right)$ and average taxonomic distinctness $(\Delta+)$ were also modelled. An important attribute of $\Delta+$ is that it is independent of sampling effort. It is defined as the average taxonomic path length between 2 randomly chosen species in the assemblage (Clarke \& Warwick 1998). The 2 diversity indices were calculated using the PRIMER-E package (Clarke \& Gorley 2001). Unlike individual species data, the data for number of taxa, total number of individuals, Shannon-Wiener diversity and taxonomic distinctness contained few zero values, and thus we were able to develop models to predict both the maximum and minimum values over the range of sediment mud content.

\section{RESULTS}

\section{Selection of species for modelling}

In total, 92 taxa were identified from the survey. Species were selected for modelling if they were found at more than 7 of the 19 sites, as this gave us a reasonable data set on which to develop models for individual species (Table 2). This resulted in the selection of 13 species that are common numerically dominant members of the macrobenthic communities of intertidal flats. 
These species represent different phyla, functional groups and life histories. No small crustaceans (amphipods, isopods or cumaceans) met the selection criteria.

\section{Environmental variables}

Overall, the data encompassed a wide range of variability in environmental characteristics, both along transects within each location, and between locations (Table 3). The change in elevation along transects equated to height changes of between 40 and $10 \mathrm{~cm}$. Comparison of the elevation with the tidal range for each location (Table 1) indicated that transects were generally around mid-tide level. Sediment organic content was always low (as is typical of New Zealand estuaries), although benthic chlorophyll a concentrations were variable and consistent with shallow marine ecosystems (Cahoon \& Safi 2002). Fig. 2 illustrates the range of sediment mud content sampled along the mud-to-sand transect in each estuary. Locations with lowest mean percent mud content also tended to exhibit the smallest variation in mud content. Table 3 indicates the range of other environmental conditions encompassed and thus reflects the environmental scope of the statistical models developed from this data.
Table 2. Species selected for statistical modelling and their general feeding strategy

\begin{tabular}{|c|c|c|}
\hline Taxon & Species & Feeding mode \\
\hline \multicolumn{3}{|l|}{ Polychaetes } \\
\hline \multirow[t]{4}{*}{ Spionids } & Aonides oxycephala & Surface deposit-feeder \\
\hline & Aquilaspio aucklandica & Surface deposit-feeder \\
\hline & Boccardia syrtis & Surface deposit-feeder \\
\hline & Scolecolepides benhami & Surface deposit-feeder \\
\hline Capitellid & Heteromastus filiformis & Subsurface deposit-feeder \\
\hline Orbinid & Scoloplos cylindifer & Surface/subsurface deposit-feeder \\
\hline Nereid & Nicon aestuariensis & Surface deposit-feeder/omnivore \\
\hline \multicolumn{3}{|l|}{ Bivalves } \\
\hline Venerid & Austrovenus stutchburyi & Suspension-feeder \\
\hline Erycinid & Arthritica bifurca & Deposit-feeder \\
\hline Tellinid & Macomona liliana & $\begin{array}{l}\text { Surface deposit-feeder/ } \\
\text { suspension-feeder }\end{array}$ \\
\hline Nuculid & Nucula hartvigiana & Surface deposit-feeder \\
\hline \multicolumn{3}{|l|}{ Crustaceans } \\
\hline Brachyuran & Helice crassa & Surface deposit-feeder/predator \\
\hline \multicolumn{3}{|l|}{ Cnidaria } \\
\hline Anthozoan & Anthopleura aureoradiata & Predator \\
\hline
\end{tabular}

\section{Preliminary inspection of data}

Prior to developing models based on the sediment mud fraction, we investigated correlations between percent mud and the other environmental variables measured along the mud-to-sand transect. Models of the relationships between percent mud and the other sediment environmental variables, although significant, did not explain a large proportion of the variability in the data $\left(\mathrm{r}^{2}=0.11, \mathrm{p}<0.001\right.$ for shear stress;

Table 3. Variability in environmental parameters measured along transects. Data for each variable are min., mean, max., respectively

\begin{tabular}{|c|c|c|c|c|c|c|}
\hline Site & $\begin{array}{l}\text { Shear stress } \\
\left(\mathrm{kg} \mathrm{cm}^{-2}\right)\end{array}$ & $\begin{array}{l}\text { Penetrability } \\
\left(\mathrm{kg} \mathrm{cm}^{-2}\right)\end{array}$ & $\begin{array}{l}\text { Elevation } \\
\quad(\mathrm{m})\end{array}$ & $\begin{array}{c}\text { Organic content } \\
(\%)\end{array}$ & $\begin{array}{l}\text { Benthic chl } a \\
\quad\left(\mu g^{-1}\right)\end{array}$ & $\begin{array}{c}\text { Coarse sediment } \\
(>500 \mu \mathrm{m}) \%\end{array}$ \\
\hline Ahuriri & $0.5,1.4,1.9$ & $0.2,2.4,5.0$ & $0.4,0.4,0.5$ & $0.7,0.9,1.4$ & $4.3,6.3,8.9$ & $0.0,0.3,0.8$ \\
\hline Bowentown & $1.0,1.2,1.5$ & $0.0,0.8,1.8$ & $0.5,0.7,0.8$ & $2.3,3.6,5.1$ & $14.6,22.5,33.8$ & $0.4,4.7,10.2$ \\
\hline Kawhia & $0.6,0.8,1.0$ & $0.3,0.8,1.1$ & $0.5,0.7,1.1$ & $1.1,1.8,3.9$ & $6.3,8.7,12.6$ & $0.5,3.9,8.7$ \\
\hline Koutou & $0.4,0.8,1.1$ & $0.3,1.5,3.9$ & $0.8,0.9,1.2$ & $1.1,2.8,5.5$ & $6.4,9.9,13.2$ & $14.5,29.0,48.9$ \\
\hline Manaia & $1.0,1.1,1.3$ & $0.8,1.9,3.9$ & $0.9,1.0,1.2$ & $3.3,4.5,5.5$ & $0.7,12.8,21.6$ & $6.0,18.6,33.1$ \\
\hline Mangawhai & $0.9,1.5,1.9$ & $2.5,3.8,5.0$ & $0.6,0.7,0.9$ & $0.5,0.9,1.5$ & $2.7,11.1,15.6$ & $0.5,1.0,1.6$ \\
\hline Manukau & $0.3,1.0,1.3$ & $0.1,2.2,4.1$ & $0.6,0.8,1.0$ & $0.7,1.1,2.3$ & $7.6,10.1,12.9$ & $0.0,0.8,1.8$ \\
\hline Matakana & $0.1,0.8,1.3$ & $6.1,8.0,9.8$ & $0.8,0.9,0.9$ & $1.2,1.7,2.2$ & $3.9,12.4,16.3$ & $0.2,0.6,1.5$ \\
\hline Mangonui & $0.3,1.3,2.4$ & $0.5,1.6,4.0$ & $0.1,0.3,0.5$ & $2.4,2.9,22.7$ & $8.2,15.8,22.7$ & $2.5,4.2,8.6$ \\
\hline Ngunguru & $0.7,1.0,1.1$ & $0.2,2.0,3.8$ & $0.5,0.7,0.9$ & $0.5,2.6,7.1$ & $2.9,15.5,26.5$ & $0.9,4.5,8.8$ \\
\hline Ohiwa & $0.1,0.6,1.0$ & $0.1,0.5,1.5$ & $0.9,1.0,1.0$ & $1.4,2.0,3.2$ & $9.0,16.3,23.4$ & $5.7,10.5,15.8$ \\
\hline Otamatea & $0.5,1.7,2.6$ & $0.1,2.5,5.0$ & $0.6,0.7,0.9$ & $0.6,1.1,3.1$ & $4.1,8.7,22.8$ & $0.4,25.1,58.4$ \\
\hline Porangahau & $0.3,0.7,1.5$ & $0.1,0.6,1.4$ & $0.9,1.0,1.0$ & $0.4,1.1,1.7$ & $2.9,6.2,14.3$ & $0.0,0.1,0.2$ \\
\hline Te Puna & $0.1,0.6,1.5$ & $0.0,0.4,1.0$ & $0.8,0.9,1.0$ & $2.6,4.0,6.0$ & $26.0,32.0,49.4$ & $2.4,6.2,10.0$ \\
\hline Waiheke & $0.8,2.5,4.2$ & $0.1,1.7,3.2$ & $1.0,1.0,1.1$ & $0.9,1.7,2.8$ & $4.8,10.9,14.1$ & $0.1,7.3,30.1$ \\
\hline Waiotahi & $0.4,1.0,1.6$ & $0.3,1.8,3.8$ & $0.6,0.7,0.7$ & $0.9,2.0,2.8$ & $11.5,16.3,19.1$ & $0.2,4.1,14.2$ \\
\hline Whangape & $0.8,1.4,2.0$ & $0.0,1.6,3.7$ & $0.3,0.4,0.6$ & $0.9,2.3,4.2$ & $2.7,4.9,9.5$ & $0.2,2.2,5.7$ \\
\hline Waikopua & $1.2,1.7,2.4$ & $0.6,3.8,5.0$ & $0.5,0.7,0.9$ & $0.6,1.0,1.5$ & $3.6,6.9,9.9$ & $0.0,0.5,1.6$ \\
\hline Whitianga & $0.4,0.7,1.2$ & $0.0,0.7,3.4$ & $0.8,0.9,1.2$ & $2.5,5.1,8.1$ & $2.5,23.6,28.8$ & $0.4,4.9,14.8$ \\
\hline
\end{tabular}




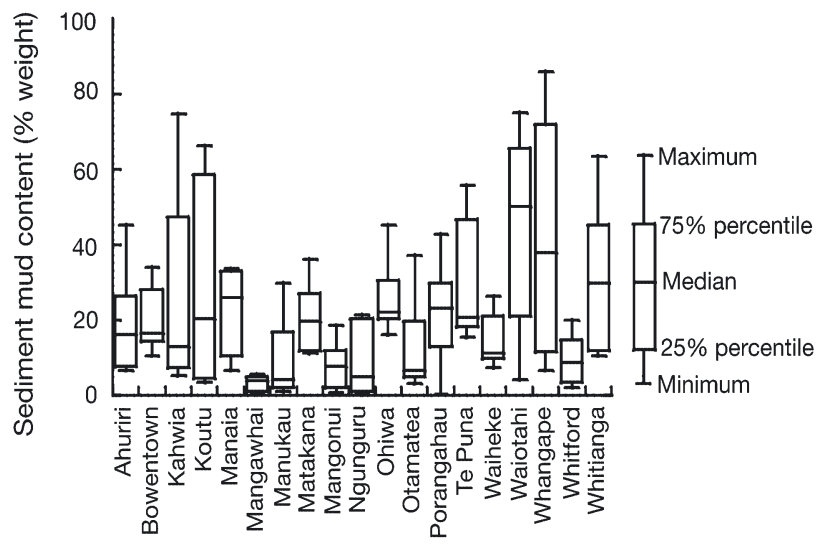

Fig. 2. Box plot of sediment mud content measured over transect at each site $\mathrm{r}^{2}=0.19, \mathrm{p}<0.001$ for penetrability; $\mathrm{r}^{2}=0.002, \mathrm{p}=$ 0.4621 for elevation; $r^{2}=0.13, p<0.001$ for organic content; $\mathrm{r}^{2}=0.07, \mathrm{p}<0.001$ for chlorophyll $a_{;} \mathrm{r}^{2}=0.02, \mathrm{p}<$ 0.001 for \% coarse sediment; $\mathrm{n}=228$ for each model). Scatterplots of species abundances and sediment mud fraction were typical of the sort described by Thomson et al. (1996) as 'factor ceilings', i.e. widely scattered beneath an upper limit (these plots are not presented here for brevity); 3-dimensional scatterplots of the species abundances, sediment mud fraction and either elevation, coarse sediment fraction or sediment organic content suggested that the variability in the response to sediment mud fraction would not be reduced by using another factor (e.g. sediment organic content) to split the dataset, as suggested by Thomson et al. (1996).

Table 4. Logistic regression models of species occurrence. $p(x)$ is the estimated probability that the species occurs

\begin{tabular}{|c|c|c|c|c|}
\hline Species & Concordance \% & $\mathrm{p}$ (model) & Model & \\
\hline Austrovenus stutchburyi & 66.7 & 0.0265 & $p(x)=$ & $\frac{\mathrm{e}^{4.55-0.72 \ln \mathrm{mud}}}{1+\mathrm{e}^{4.55-072 \ln \mathrm{mud}}}$ \\
\hline Anthopleura aureoradiata & 67.4 & 0.0004 & $p(x)=$ & $\frac{\mathrm{e}^{0.90-0.045 \mathrm{mud}}}{1+\mathrm{e}^{0.90-0.045 \mathrm{mud}}}$ \\
\hline Aonides oxycephala & 73.4 & $<0.0001$ & $p(x)=$ & $\frac{\mathrm{e}^{1.16-0.05 \mathrm{mud}}}{1+\mathrm{e}^{1.16-0.05 \mathrm{mud}}}$ \\
\hline Crab burrows & 72.3 & $<0.0001$ & $p(x)=$ & $\frac{\mathrm{e}^{0.68+0.075 \mathrm{mud}}}{1+\mathrm{e}^{0.68-0.075 \mathrm{mud}}}$ \\
\hline Helice crassa & 75.1 & $<0.0001$ & $p(x)=$ & $\frac{\mathrm{e}^{-2.95+1.07 \ln \operatorname{mud}}}{1+\mathrm{e}^{-2.95+1.07 \ln \mathrm{mud}}}$ \\
\hline Scoloplos cylindifer & 67.9 & 0.0123 & $p(x)=$ & $\frac{\mathrm{e}^{-0.33+0.06 \mathrm{mud}-0.002 \mathrm{mud}^{2}}}{1+\mathrm{e}^{-0.33+0.06 \mathrm{mud}-0.002 \mathrm{mud}^{2}}}$ \\
\hline Macomona liliana & 64.1 & 0.0074 & $p(x)=$ & $\frac{\mathrm{e}^{0.76+0.69 \ln \text { mud }-0.21 \operatorname{ln~mud}^{2}}}{1+\mathrm{e}^{0.76+0.69 \ln \text { mud }-0.21 \ln \text { mud }^{2}}}$ \\
\hline Nucula hartvigiana & 70.2 & 0.0024 & $p(x)=$ & $\frac{\mathrm{e}^{2.27-0.63 \ln \mathrm{mud}}}{1+\mathrm{e}^{2.27-0.63 \ln \mathrm{mud}}}$ \\
\hline Aquilaspio aucklandica & 67.4 & 0.0265 & $p(x)=$ & $\frac{\mathrm{e}^{0.64+0.13 \mathrm{mud}-0.0019 \mathrm{mud}^{2}}}{1+\mathrm{e}^{0.64+0.13 \mathrm{mud}-0.0019 \mathrm{mud}^{2}}}$ \\
\hline Arthritica bifurca & 69.9 & $<0.0001$ & $p(x)=$ & $\frac{\mathrm{e}^{-1.31+0.134 \mathrm{mud}-0.002 \mathrm{mud}^{2}}}{1+\mathrm{e}^{-1.31+0.134 \mathrm{mud}-0.002 \mathrm{mud}^{2}}}$ \\
\hline Nicon aestuariensis & 65.7 & 0.0098 & $p(x)=$ & $\frac{\mathrm{e}^{-0.44+0.61 \ln \mathrm{mud}}}{1+\mathrm{e}^{-0.44+0.61 \ln \mathrm{mud}}}$ \\
\hline Boccardia syrtis & 81.7 & $<0.0001$ & $p(x)=$ & $\frac{\mathrm{e}^{-2.95+0.33 \mathrm{mud}-0.007 \mathrm{mud}^{2}}}{1+\mathrm{e}^{-2.95+0.33 \mathrm{mud}-0.007 \mathrm{mud}^{2}}}$ \\
\hline Heteromastus filiformis & 64.5 & 0.0135 & $p(x)=$ & $\frac{\mathrm{e}^{0.36+0.45 \ln \mathrm{mud}}}{1+\mathrm{e}^{0.36+0.45 \ln \mathrm{mud}}}$ \\
\hline Scolecolepides benhami & 59.4 & 0.0802 & $p(x)=$ & $\frac{\mathrm{e}^{-0.22+0.27 \ln \text { mud }}}{1+\mathrm{e}^{-0.22+0.27 \ln \mathrm{mud}}}$ \\
\hline
\end{tabular}




\section{Predicting probability of species occurrence}

Logistic regression models were developed for each species; these models show a concordance of between 59.4 and $81.7 \%$ (Table 4 ). The models reveal a wide variety of functional forms, indicating that the occurrence of species is influenced by species-specific sensitivity to sediment mud content. None of the models developed indicated that the probability of occurrence of an individual species changes at a constant rate as a function of sediment mud content (Fig. 3). Curvilinear models showed a strong positive effect of increasing sediment mud content on predictions of occurrence for Helice crassa, crab burrows, Scolecolepides benhami, Nicon aestuariensis and Heteromastus filiformis, and a negative effect for Austrovenus stutchburyi, Macomona liliana, Nucula hartvigiana, Aonides oxycephala and Anthopleura aureoradiata. Generally, the models predicted the occurrence of the individual species over a wide range of probabilities of occurrence. However, the models developed for A. stutchburyi, S. benhami, N. aestuariensis and H. filiformis only predict occurrence over a limited range of probabilities, indicating that the occurrence of these species is not sensitive to a wide range of sediment mud content. For example, A. stutchburyi, although more likely to occur in sediments with low mud content, still has a $75 \%$ chance of being found in $80 \%$ mud. Four species (Aquilaspio aucklandica, Arthritica bifurca, Boccardia syrtis and Scoloplos cylindifer) exhibited Gaussian response models, reflecting the highest probability of occurrence at intermediate sediment mud content.

\section{Predicting maximum density of species}

While models predicting the occurrence of species were relatively simple, the models developed to predict the maximum density in relation to sediment mud content were more complex and varied substantially between species (Table 5, Fig. 4). Most models effec-

Table 5. Regression models based on maximum density

\begin{tabular}{|c|c|c|c|}
\hline Species & $r^{2}$ & $\mathrm{p}$ (model) & Model \\
\hline Austrovenus stutchburyi & 0.86 & 0.0003 & Max. density = $118.6-25.2 \ln (\mathrm{mud})$ \\
\hline Anthopleura aureoradiata & 0.95 & $<0.0001$ & Max. density = $48.5-11.8 \ln ($ mud) \\
\hline Aonides oxycephala & 0.75 & 0.0011 & Max. density $=147.2-31.7 \ln (\mathrm{mud})$ \\
\hline Crab burrows & 0.28 & 0.1439 & Max. density $=65.3+0.59$ mud \\
\hline Helice crassa & 0.20 & 0.2315 & Max. density $=9.14+0.042$ mud \\
\hline Scoloplos cylindifer & 0.93 & $<0.0001$ & Max. density $=90.8-21.9 \ln ($ mud $)$ \\
\hline Macomona liliana & 0.78 & 0.0048 & Max. density $=21.6+0.146 \mathrm{mud}-0.005 \mathrm{mud}^{2}$ \\
\hline Nucula hartvigiana & 0.66 & 0.0080 & Max. density $=35.3-0.57$ mud \\
\hline Aquilaspio aucklandica & 0.64 & 0.0286 & Max. density $=18.4+0.75 \mathrm{mud}-0.012 \mathrm{mud}^{2}$ \\
\hline Arthritica bifurca & 0.77 & 0.0054 & Max. density $=32.7 \mathrm{e}^{-0.5[(\operatorname{mud}-28.1) / 15.6]^{2}}$ \\
\hline Nicon aestuariensis & 0.63 & 0.062 & Max. density $=48.1 \mathrm{e}^{-0.5[(\operatorname{mud}-36.5) / 21.3]^{2}}$ \\
\hline Boccardia syrtis & 0.77 & 0.006 & Max. density $=0.28+8.2 \mathrm{e}^{-0.5[(\operatorname{mud}-24.3) / 11.6]^{2}}$ \\
\hline Heteromastus filiformis & 0.89 & 0.0065 & Max. density $=24.6+59.5 \mathrm{e}^{-0.5[(\operatorname{mud}-29.1) / 14.7]^{2}}$ \\
\hline Scolecolepides benhami & 0.92 & 0.0012 & Max. density $=27.3 \mathrm{e}^{-0.5[(\operatorname{mud}-19.8) / 8.1]^{2}}$ \\
\hline
\end{tabular}


Table 6. Regression models based on maximum or minimum values of community variables. $H^{\prime}$ : Shannon-Wiener diversity; $\Delta+$ : average taxonomic distinctness

\begin{tabular}{|llcll}
\hline Variable & & $\mathrm{r}^{2}$ & $\mathrm{p}$ (model) & \multicolumn{1}{c}{ Model } \\
\hline Maximum & No. of taxa & 0.95 & $<0.0001$ & Max. taxa $=21.7-0.17$ mud \\
& No. of individuals & 0.97 & $<0.0001$ & Max. indiv. $=271.7-3.12$ mud \\
& Shannon-Wiener diversity & 0.82 & 0.0003 & Max. $H^{\prime}=2.65-0.13$ mud \\
& Taxonomic distinctness & 0.85 & 0.0002 & Max. $\Delta+=101.1-0.20$ mud \\
Minimum & No. of taxa & 0.75 & 0.0012 & Min. taxa $=1.10+0.063$ mud \\
& No. of individuals & 0.52 & 0.0203 & Min. indiv. $=4.42+0.17$ mud \\
& Shannon-Wiener diversity & 0.81 & 0.0004 & Min. $H^{\prime}=-0.77+0.45$ logemud \\
& Taxonomic distinctness & 0.11 & 0.3513 & Min. $\Delta+=72.2+0.051$ mud \\
\hline
\end{tabular}

tively explained variability in the distribution of maximum density $\left(\mathrm{r}^{2}>0.60\right)$, except for the mud crab Helice crassa, for which only $20 \%$ of the variability in maximum density could be explained. The model for crab-burrow density was not substantially better. The functional form of the model developed to predict maximum abundance relative to sediment mud content varied from simple linear relationships ( $H$. crassa, crab burrows and Nucula hartvigiana), curvilinear relationships (Austrovenus stutchburyi, Anthopleura aureoradiata, Aonides oxycephala and Scoloplos cylindifer), and second-order polynomial relationships (Macomona liliana and Aquilaspio aucklandica) to gaussian response curves (Arthritica bifurca, Nicon aestuariensis, Boccardia syrtis, Heteromastus filiformis and Scolecolepides benhami). Variations in the functional form of these models indicated species-dependent sensitivity to sediment mud content. Crab burrows

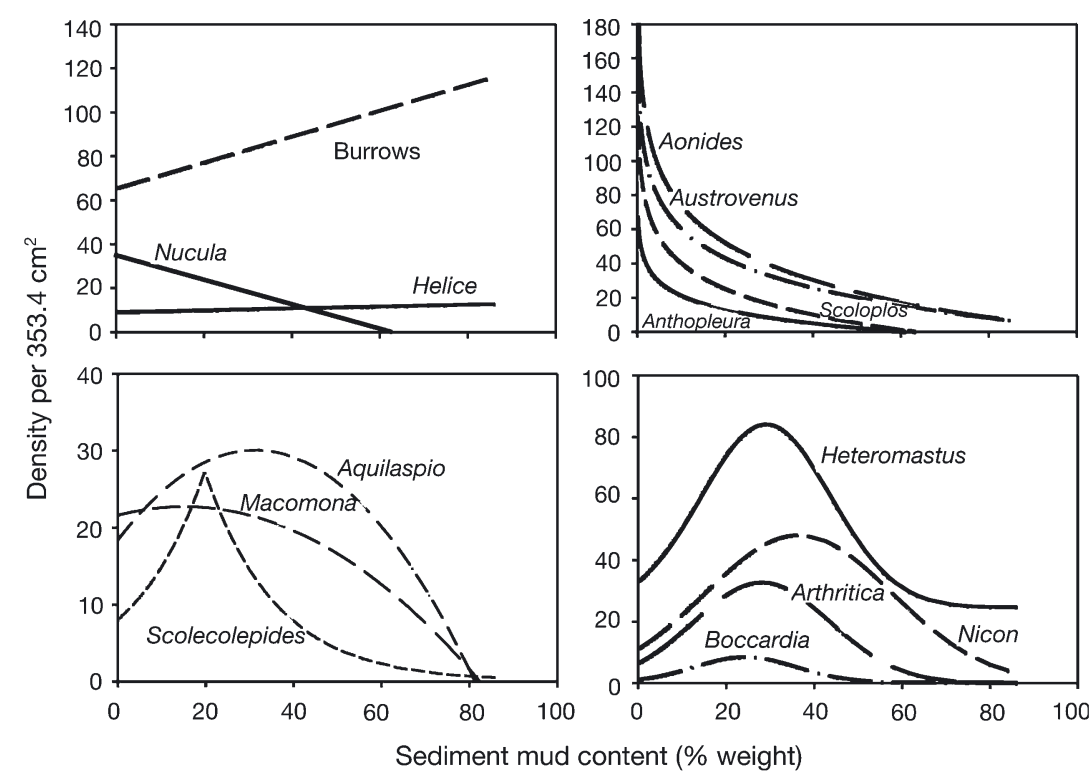

Fig. 4. Maximum density regression models for 13 species and density of crab burrows relative to sediment mud content. Full specific names in Table 2 were the only variable that showed a monotonic increase in maximum density over the entire range of sediment mud content. Although most models predicted a wide range of maximum densities relative to the 10 categories of sediment mud content, the predicted change in maximum density of $H$. crassa and $B$. syrtis indicated that their density did not change substantially over the range of sediment mud content (Fig. 4).

\section{Predicting maximum and minimum values for community level variables}

For number of individuals, number of taxa, ShannonWiener diversity and taxonomic distinctness, the minimum-value model was less effective at explaining variability than the maximum-value model (Table 6). However, in each case the maximum and minimum models defined wedge-shaped data distributions indicative of decreases in variability of both maximum density and species diversity with increasing sediment mud content (Fig. 5). The similar trends apparent for both Shannon-Wiener diversity and taxonomic distinctness imply a consistency in response irrespective of differences in sample size across the 10 categories of sediment mud content.

\section{DISCUSSION}

Models relating the distribution and abundance of common intertidal macrofaunal species, total density and diversity to sediment mud content were successfully developed. These models were based on the distribution of large macrofauna ( $\geq 1.0 \mathrm{~mm}$ ) and made use of a novel sampling design that restricted the potential 


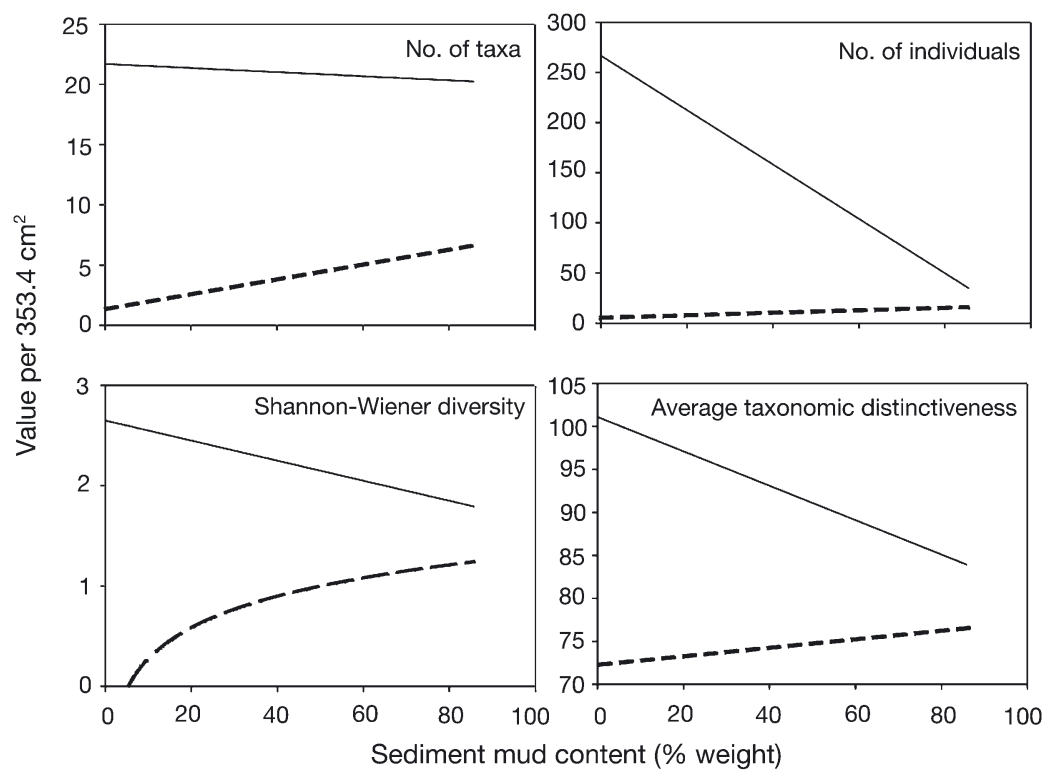

Fig. 5. Maximum and minimum values predicted from regression models of community level variables relative to sediment mud content

the role of sediment mud content as a factor limiting maximum density rather than controlling mean density over broad spatial scales. While the poor performance of the standard ordinary least-squares models emphasizes the need to develop different types of statistical models, models based on presence/absence, mean or maximum density also have different ecological implications.

Forecasting maximum density can provide particular insight because of the ecological importance of high-density patches in the functional roles played by individual species. Functional roles for macrofauna include influences on sediment stability, water-column turbidity, nutrient and carbon processing and contaminant sequestering (Herman et al. 1999, Levin et al. 2001). The magnitude of the effect organisms have on these processes is often influenced by their size and density. Thus, as spatial distributions change and the presence of highdensity patches decreases, organisms can

for other factors to confound our analysis while facilitating rapid collection of data over a reasonably wide geographic and oceanographic extent. Thus, these models can be considered to be reasonably general in their ability to forecast the distribution and abundance of species associated with habitat changes mediated through changes in sediment particle size. These are broad-scale models that forecast the averaged distribution and abundance over large spatial scales (ca. $>100 \mathrm{~m}$ ), and should not be expected to resolve abundances on a metre-by-metre basis. An important challenge in the heuristic improvement of this type of model is to assess its usefulness over different space and time scales.

Similar to the results of Ysebaert et al. (2002), logistic regression was found to be a useful approach for predicting the occurrence of species along the mud-tosand gradient. The 'factor ceiling' concept of Thomson et al. (1996) and the methods of Blackburn et al. (1992) were also valuable in predicting the maximum abundance of species; especially as ordinary least-squares regression based on means performed poorly in modelling the variability in the density of individual species relative to sediment mud content. The 2 polychaetes Scoloplos cylindifer and Aonides oxycephala illustrate this problem, with standard mean-based ordinary least-squares model statistics of $\mathrm{p}=0.1517$, $\mathrm{r}^{2}=0.012 ; \mathrm{p}<0.0001, \mathrm{r}^{2}=0.108$ respectively; $\mathrm{cf}$. the ordinary least-squares regressions based on maximum density in Table 5. The poor performance of models fitted to the centre of the response distribution reflects become functionally extinct and fail to contribute to community and ecosystem functions (Dayton et al. 1998). Modelling the maximum possible density-response curve then becomes a step towards providing insight into the threat that loss of habitat diversity may pose for both the resilience of all levels of biological diversity and the provision of ecosystem services.

Comparisons of the relative sensitivity of the different species to changes in sediment mud content were made using Figs. $3 \& 4$. Both types of models revealed wide variations in response to sediment mud content on the part of the 4 surface deposit-feeding species of spionid polychaetes (Aonides oxycephala, Aquilaspio aucklandica, Boccardia syrtis and Scolecolepides benhami). A. oxycephala appeared to be the most sensitive to increases in mud content, while A. aucklandica appeared to prefer 20 to $50 \%$ mud. These apparent differences in habitat preference have important implications for the generalities drawn from studies of low taxonomic resolution or aggregative indices of ecological change or ecosystem 'health'. We could not distinguish any overall response to increased mud content that appeared related to feeding type or mobility. Species with a preference for low mud content included the mobile suspension-feeding Austrovenus, as well as the predator (Anthopleura stutchburyi) and 2 deposit feeders (A. oxycephala and Nucula hartvigiana). Species with preferences for the higher mud contents were the scavenging and burrowing crab (Helice crassa), a sediment-living omnivore (Nicon aestuariensis) and a small sedentary deposit-feeder (Arthritica bifurca). 
Given the purported tolerance of estuarine species to environmental conditions, it is interesting that we can develop models showing a wide range of probabilities of occurrence and density. However, for some species the models showed little variability in probabilities of occurrence or maximum density over a wide range of sediment mud content. This limitation was apparent for Austrovenus stutchburyi, which is particularly interesting as this is the only obligate suspensionfeeder modelled and might have been expected to be more sensitive to sediment mud content. However, A. stutchburyi occurs in a wide range of habitats, with some indication of age-dependent habitat preference (authors' pers. obs.). The polychaete Aquilaspio aucklandica and the bivalve Arthritica bifurca both exhibited very wide flat peaks of maximum probability of occurrence, although the models of maximum density exhibited narrower peaks at similar mud contents. Another possible explanation for the low variability in probabilities of occurrence or maximum density over a wide range of sediment mud content is that these species are not strongly constrained by sediment particle size over the mud-to-sand transition zone. However, the data set used to develop these models did encompass a wide range of environmental characteristics (Tables 1 \& 3).

Many species exhibited similar functional forms for models of both the probability of occurrence and maximum density; however, there are some interesting discrepancies. For Scoloplos cylindifer, the maximum density model (Fig. 4) predicted a stronger preference for low sediment mud content than the probability of occurrence model (Fig. 3). More species were modelled as monotonic functions of sediment mud content when predicting occurrence rather than maximum density. Nicon aestuariensis, Heteromastus filiformis and Scolecolepides benhami all exhibited increasing probabilities of occurrence with increasing sediment mud content, yet exhibited peak densities at low-tomoderate mud content. However, in these 3 cases, most of the predicted increases in probability of occurrence with increasing sediment mud content occurred at relatively low percentages (20 to $40 \%$ ). The functional form of the 2 types of model generally showed that more species exhibited more distinct peaks in maximum density and steeper response curves along the gradient of sediment mud content than was apparent in models of the probability of occurrence (e.g. cf. Macomona liliana and Aquilaspio aucklandica in Figs. 3 \& 4). Austrovenus stutchburyi also showed a much clearer response in terms of maximum density than probability of occurrence, indicating greater sensitivity in species preferences in terms of maximum density than occurrence alone. An exception to this was Helice crassa, although we could not develop a powerful model explaining the density of this species. The generally elevated sensitivity of the maximumdensity models over those predicting occurrence is to be expected, given that species may occur over a wide range of habitats, although high densities are only reached under a constricted range of the environmental conditions.

Community-level changes along the mud-to-sand gradient revealed some interesting patterns in abundance, equitability and taxonomic distinctness. The decrease in total density with increasing sediment mud content is at first counterintuitive, as often intertidal muddy habitats contain low diversity but high densities. This pattern is probably a reflection of our focus on the density of large macrofauna retained on a $1.0 \mathrm{~mm}$-mesh screen. Differences in the slope of the lines for maximum values for the number of taxa and the 2 diversity indices indicate that although the number of taxa only decreases very slightly with increasing sediment mud content, the distribution of individuals amongst taxa becomes less equitable and the taxa are drawn from a restricted phylogenetic pool.

Correlative studies do not provide proof of causal ecological hypotheses, but they may be useful in forecasting change over the range of environmental conditions sampled. Turning correlative models into predictive models requires developing an understanding of the mechanisms that underpin the relationships. Experiments carried out on the mud-to-sand habitat gradient can reveal habitat-dependent responses in local biological processes (Hewitt et al. 1996, Thrush et al. 1996, Whitlatch et al. 2001). These responses are likely to be complex interactions between life history, feeding, reproduction and mobility of species, and hydrodynamic and biogeochemical processes, that will require detailed study to resolve (Snelgrove \& Butman 1994, Schaffner et al. 2001, Ellis et al. 2002). Nevertheless, corroborative evidence from recent experiments on the effects of catastrophic sediment runoff and deposition in estuaries on macrofauna provides some mechanistic links (Peterson 1985, Wulff et al. 1997, Miller et al. 2002, Norkko et al. 2002). In the absence of simple mechanistic understanding, statistical models that are able to forecast the distribution and abundance of species are useful from both an ecological and environmental management perspective. Such models indicate the long-term consequences of habitat change and, where possible, should be used in conjunction with other approaches that predict the potential for chronic degradative change due to the mismatch of the space and time scales of disturbance and macrobenthic recovery (e.g. Thrush \& Whitlatch 2001, Thrush et al. in press).

Habitat change is generally recognised as a major threat to biodiversity, yet the lack of statistical models for marine soft-sediment ecosystems is a major limita- 
tion to our predictive ability (Constable 1999). It is important that a heuristic approach is taken in developing such models, as they need to be both tested and iteratively developed across a range of spatial scales as well as supported by improved mechanistic understanding. Inevitably, for many large-scale environmental issues, there is a lack of both appropriate controls and an ability to rigorously demonstrate cause-effect relationships. Thus, application of such models must be cognizant of the trade-off between confidence and generality in environmental information and the need for a more integrative process of predicting and testing large-scale effects (Thrush et al. 1999).

Acknowledgements. We thank Kate Edenborough, Sean Holland, Joanna Norkko, Vonda Cummings and Diane Schultz for their help with fieldwork and sample processing. We also greatly appreciate the advice provided by Calum Bonnington, Kevin Robinson, Gloria and Jim Herbert, Chris Hatton, Dominic McCarthy, Stephanie Turner, Peter Te Moananui, Peter Johnson, Angeline Greensill, Stephen Parks, Anita Anderson and Alan Wakefield in recommending sampling locations and providing local information. We thank Nicole Hancock for figure production and Vonda Cummings, Carolyn Lundquist and Drew Lohrer for comments on early drafts of the manuscript. The research was funded by the Foundation for Research Science and Technology (NZ) C01X0024.

\section{LITERATURE CITED}

Beukema JJ (1976) Biomass and species richness of the macrobenthic animals living on tidal flats of the Dutch Wadden-Sea. Neth J Sea Res 10:236-261

Blackburn TM, Lawton JH, Perry JN (1992) A method of estimating the slope of upper bounds of plots of body size and abundance in natural animal assemblages. Oikos 65: $107-112$

Burkett V, Codignotto JO, Forbes DL, Mimura N, Beamish RJ, Ittekkot V (2001) Coastal zones and marine ecosystems. In: McCarthy JJ, Caziani OF, Leary NA, Dokken DJ, White KS (eds) Climate change 2001: impacts, adaptation and vulnerability. Cambridge University Press, Cambridge, p 343-380

Butman CA (1987) Larval settlement of soft-sediment invertebrates: the spatial scales of pattern explained by active habitat selection and the emerging role of hydrological processes. Oceanogr Mar Biol Annu Rev 25:113-165

Cahoon LB, Safi KA (2002) Distribution and biomass of benthic microalgae in Manukau Harbour, New Zealand. New Zealand J Mar Freshw Res 36:257-266

Clarke KR, Gorley RN (2001) Primer version 5. Primer-E, Plymouth

Clarke KR, Warwick RM (1998) A taxonomic distinctness index and its statisitical properties. J Appl Ecol 35:523-531

Constable AJ (1999) Ecology of benthic macro-invertebrates in soft-sediment environments: a review of progress towards quantitative models and predictions. Aust J Ecol 24:452-476

Cummings V, Thrush S, Hewitt J, Norkko A, Pickmere S (2003) Terrestrial deposits on interdial sandflats: sediment characteristics as indicators of habitat suitability for recolonising macrofauna. Mar Ecol Prog Ser 253:39-54
Dayton PK, Tegner MJ, Edwards PB, Riser KL (1998) Sliding baselines, ghosts, and reduced expectations in kelp forest communities. Ecol Appl 8:309-322

Ellis J, Cummings V, Hewitt J, Thrush S, Norkko A (2002) Determining effects of suspended sediment on condition of a suspension feeding bivalve (Atrina zelandica): results of a survey, a laboratory experiment and a field transplant experiment. J Exp Mar Biol Ecol 267:147-174

Fowler AM, Hennessey KJ (1995) Potential impacts of global warming on the frequency and magnitude of heavy precipitiation. Nat Hazards 11:283-303

Gray JS (1974) Animal-sediment relationships. Oceanogr Mar Biol Annu Rev 12:707-722

Herman PMJ, Middelburg JJ, VandeKoppel J, Heip CHR (1999) Ecology of estuarine macrobenthos. Adv Ecol Res 29:195-231

Hewitt JE, Thrush SF, Cummings VJ, Pridmore RD (1996) Matching patterns with processes: predicting the effect of size and mobility on the spatial distributions of the bivalves Macomona liliana and Austrovenus stutchburyi. Mar Ecol Prog Ser 135:57-67

Hewitt JE, Legendre P, McArdle BH, Thrush SF, Bellehumeur C, Lawrie SM (1997a) Identifying relationships between adult and juvenile bivalves at different spatial scales. J Exp Mar Biol Ecol 216:77-98

Hewitt JE, Pridmore RD, Thrush SF, Cummings VJ (1997b) Assessing the short-term stability of spatial patterns of macrobenthos in a dynamic estuarine system. Limnol Oceanogr 42:282-288

Hewitt JE, Cummings VJ, Ellis JI, Funnell GA, Norkko A, Talley TS, Thrush SF (2003) The role of waves in the colonisation of terrestrial sediments deposited in the marine environment. J Exp Mar Biol Ecol 290:19-48

Legendre P, Legendre L (1998) Numerical ecology. Elsevier, Amsterdam

Legendre P, Thrush SF, Cummings VJ, Dayton PK and 9 others (1997) Spatial structure of bivalves in a sandflat: scale and generating processes. J Exp Mar Biol Ecol 216: 99-128

Levin LA, Boesch DF, Covich A, Dahm C and 8 others (2001) The function of marine critical transition zones and the importance of sediment biodiversity. Ecosystems 4 : $430-451$

Mannino A, Montagna PA (1997) Small-scale spatial variation in macrobenthic community structure. Estuaries 20: 159-173

McArdle BH, Blackwell RG (1989) Measurement of density variability in the bivalve Chione stutchburyi using spatial autocorrelation. Mar Ecol Prog Ser 52:245-252

Meire PM, Seys J, Buijs J, Coosen J (1994) Spatial and temporal patterns of intertidal macrobenthic populations in the Oosterschelde: are they influenced by the construction of the storm-surge barrier? Hydrobiol 282/283:157-182

Miller DC, Muir CL, Hauser OA (2002) Detrimental effects of sedimentation on marine benthos: what can be learned from natural processes and rates? Ecol Eng 19:211-232

Norkko A, Thrush SF, Hewitt JE, Cummings VJ and 5 others (2002) Smothering of estuarine sandflats by terrigenous clay: the role of wind-wave disturbance and bioturbation in site-dependent macrofaunal recovery. Mar Ecol Prog Ser 234:23-41

Peterson CH (1985) Patterns of lagoonal bivalve mortality after heavy sedimentation and their paleoecological significance. Paleobiol 11:139-153

Probert PK (1984) Disturbance, sediment stability and trophic structure of soft-bottom communities. J Mar Res 42: 893-921 
Rhoads DC, Young DK (1970) The influence of depositfeeding organisms on sediment stability and community trophic structure. J Mar Res 28:150-178

Sartory DP (1982) Spectrophotometric analysis of chlorophyll $a$ in freshwater phytoplankton. Tech Rep TR 115. Hydrological Research Institute, Pretoria

Schaffner LC, Dellapenna TM, Hinchey EK, Friedrichs CT, Thompson Neubauer M, Smith ME, Kuehl SA (2001) Physical energy regimes, seabed dynamics and organism-sediment interactions along an estuarine gradient. In: Aller JY, Woodin SA, Aller RC (eds) Organism-sediment, interactions, Vol 21. University of South Carolina, Columbia, p 159-179

Snelgrove PVR, Butman CA (1994) Animal-sediment relationships revisited: cause versus effect. Oceanogr Mar Biol Annu Rev 32:111-177

Thomson JD, Weiblen G, Thompson BA, Alfaro S, Legendre P (1996) Untangling multiple factors in spatial distributions: lilies, gophers and rocks. Ecology 77:1698-1715

Thorson G (1950) Reproduction and larval ecology of marine bottom invertebrates. Biol Rev 25:1-45

Thrush SF (1991) Spatial patterns in soft-bottom communities. Trends Ecol Evol 6:75-79

Thrush SF, Whitlatch RB (2001) Recovery dynamics in benthic communities: balancing detail with simplification. In: Reise K (ed) Ecological comparisons of sedimentary shores. Springer-Verlag, Berlin, p 297-316

Thrush SF, Hewitt JE, Pridmore RD, Cummings VJ (1996) Adult/juvenile interactions of infaunal bivalves: contrasting outcomes in different habitats. Mar Ecol Prog Ser 132:83-92

Thrush SF, Lawrie SM, Hewitt JE, Cummings VJ (1999) The problem of scale: uncertainties and implications for soft-

Editorial responsibility: John Gray (Contributing Editor), Oslo, Norway bottom marine communities and the assessment of human impacts. In: Gray JS, Ambrose W, Szaniawska A (eds) Bieogeochemical cycling and sediment ecology. Kluwer, Dordrecht, p 195-210

Thrush SF, Hewitt JE, Norkko A, Cummings VJ, Funnell GA (2003) Catastrophic sedimentation on estuarine sandflats: recovery of macrobenthic communities is influenced by a variety of environmental factors. Ecol Appl 13: 1433-1455

Thrush SF, Lundquist CJ, Hewitt JE (in press) Spatial and temporal scales of disturbance to the seafloor: a generalized framework for active habitat management. In: Barnes PW, Thomas JP (eds) Benthic habitats and the effects of Fishing. Amercan Fisheries Society, Symposium Series, Bethesda, MD

Wheatcroft RA (2000) Oceanic flood sedimentation: a new perspective. Cont Shelf Res 20:2059-2066

Whitlatch RB, Lohrer AM, Thrush SF (2001) Scale-dependent recovery of the benthos: effects of larval and post-larval stages. In: Aller JY, Woodin SA, Aller RC (eds) Organism-sediment interactions, Vol 21. University of South Carolina, Columbia, p 181-199

Wulff A, Sundback K, Nilsson C, Carlson L, Jonsson B (1997) Effect of sediment load on the microbenthic community of a shallow-water sandy sediment. Estuaries 20:547-558

Ysebaert T, Meire P, Herman PMJ, Verbeek H (2002) Macrobenthic species response surfaces along estuarine gradients: prediction by logistic regression. Mar Ecol Prog Ser 225:79-95

Zajac RN, Whitlatch RB (1982) Responses of estuarine infauna to disturbance. II. Spatial and temporal variation in succession. Mar Ecol Prog Ser 10:15-27

Submitted: December 29, 2002; Accepted: July 28, 2003

Proofs received from author(s): November 12, 2003 